\title{
Serat Pelepah Sagu Sebagai Alternatif Pengganti Serat Sintesis Fiberglass
}

\author{
Budiawan Sulaeman ${ }^{1}$, Rakhmawati Natsir ${ }^{2}$ \\ ${ }^{1}$ Dosen Program Studi Teknik Informatika, Universitas Andi Djemma, Palopo \\ ${ }^{2}$ Dosen Program Studi Teknik Sipil, Universitas Andi Djemma, Palopo \\ E-mail: ${ }^{1}$ budiawan.unanda@yahoo.com, ${ }^{2}$ wathi07@gmail.com
}

\begin{abstract}
Abstrak
Tujuan penelitian ini untuk menganalisis pengaruh ukuran besar diameter serat pelepah sagu terhadap sifat mekanik kekuatan tarik, menganalisis sifat mekanik tarik material komposit yang diperkuat serat pelepah sagu. Berdasarkan hasil penelitian; (1). Larutan NAoH berpengaruh

Kata Kunci

Komposit; Serat; Pelepah; Tungkai daun; Sagu. terhadap kuat Tarik specimen, hal ini ditunjukkan pada 2,5\% (NAoH terhadap $\left.\mathrm{H}_{2} \mathrm{O}\right)$. Nilai kekuatan tariknya $49,486 \mathrm{~N} / \mathrm{mm}^{2}$. (2). Serat pelepah sagu kuat tariknya jauh dibawah serat gelas. $\left(48,435 \mathrm{~N} / \mathrm{mm}^{2}<323 \mathrm{~N} / \mathrm{mm}^{2}\right)$. Hal ini disebabkan rongga yang terdapat di serat sintesis lebih rapat dibanding serat alami. (3). Berdasarkan variabel yang diteliti, kekuatan tarik $\left(F^{t u}\right)$ dengan nilai tertinggi terjadi pada komposit (volume $85 \%$ matriks : $15 \%$ serat) yaitu sebesar 3,12 beban 11824 N. (4). Kekuatan tarik mengalami kenaikan terhadap peningkatan komposisi volume serat. (5). Spesimen uji yang mengalami regangan dan patah pada titik load yaitu pada komposisi volume $85 \%$ matriks : $15 \%$ serat sebesar 3,12 MPa dengan regangan sebesar $8 \%$ dan modulus young yang terjadi sebesar 38,615 MPa.
\end{abstract}

Keywords:

Composite, Fiber; Frond; Leaves, Sago;

\begin{abstract}
The purpose of this study was to analyze the effect of the size of the sago frond fiber diameter on the mechanical properties of the tensile strength, to analyze the tensile mechanical properties of the composite material reinforced by sago frond fibers. Based on research results; (1) $\mathrm{NaOH}$ solution affects the tensile strength of the specimen. This is shown at $2.5 \%$ ( $\mathrm{NaOH}$ to $\mathrm{H} 2 \mathrm{O}$ ), the tensile strength value is $49.486 \mathrm{~N} / \mathrm{mm} 2$. (2) Sago frond fiber has a tensile strength far below the glass fiber $(48,435 \mathrm{~N} / \mathrm{mm} 2<323 \mathrm{~N} / \mathrm{mm} 2)$. This is because the cavities in synthetic fibers are denser than natural fibers. (3) Based on the variables studied, the tensile strength (Ftu) with the highest value occurs in the composite (85\% matrix volume: $15 \%$ fiber), which is 3.12 load 11824 N. (4) Tensile strength increases with the increase in fiber volume composition. (5) The test specimens that experienced a strain and fracture at the load point, namely the composition of volume $85 \%$ matrix: $15 \%$ fiber was $3.12 \mathrm{MPa}$ with a strain of $8 \%$ and the modulus young that occurred was $38.615 \mathrm{MPa}$.
\end{abstract}

\section{PENDAHULUAN}

Material komposit adalah material multi fasa yang diperoleh melalui kombinasi dari dua material atau lebih yang memiliki karakteristik sifat yang berbeda, digabungkan untuk mencapai sifat karakteristik yang lebih baik yang tidak dimiliki material penyusunnya. Material komposit tersusun atas dua unsur utama yaitu matriks (bahan pengisi) dan filler (bahan pengisi) (Auwal et al, 2020). Bahan pengisi dapat berbentuk serat, partikel, serbuk, dan lain-lain (Chung, 2010). Disamping itu serat alam juga lebih gampang diperoleh, karena berasal dari mahluk hidup seperti hewan dan tumbuhan, yang bersifat dapat terbaruhkan, dapat diolah secara alami, ramah terhadap lingkungan, serta mempunyai kekakuan yang lebih tinggi dan tidak menyebabkan iritasi pada kulit (Auwal, 2019). Serat alam yang sering digunakan dan memiliki selulosa antara lain serat kelapa, serat kenaf, serat empulur sagu, serat tebu, serat rami, serat nenas, dan lain- lain (Yudha, 2014)

Kebanyakan potensi luasan tumbuhan sagu nasional terdapat di wilayah Indonesia Timur. Sagu (Metroxylon spp) sebagai salah satu tumbuhan palem yang tumbuh di daerah tropik basah, memiliki multifungsi dalam kehidupan masyarakat. Bagian empulur dari batang sagu dapat menghasilkan atau diambil patinya sebagai bahan pangan utama bagi sebagian penduduk di Sulawesi, Papua dan Maluku serta beberapa daerah lain di Indonesia Bagian Timur. Pemanfaatan tepung sagu atau aci sagu sebagai sumber karbohidrat 
di beberapa daerah terutama di pedesaan telah berlangsung lama (Ahyuni, 2011).

Dari hasil pengolahan tepung sagu meninggalkan beberapa limbah, salah satu limbah tersebut adalah tungkai daun sagu (Pelepah Sagu). Sedangakan apabila diamati secara seksama didalam kulit pelepah sagu terdapat serat yang kuat menyerupai bulu rambut. Hal ini memungkinkan bisa dimanfaatkan sebagai bahan penguat pada material komposit serat alami. Sementara itu berdasarkan potensi pengembangan sagu di Indonesia, khususnya di Kelurahan Jaya Kecamatan Telluwanua Kota Palopo, terdapat pusat pengolahan sagu. Sehingga berlimpahnya bahan baku serat pelepah sagu dan pemanfaatannya masih sebatas kerajinan Rumah rumah tangga.

Tujuan khusus penelitian ini untuk menganalisis pengaruh ukuran besar diameter serat pelepah sagu terhadap sifat mekanik kekuatan tarik, menganalisis sifat mekanik tarik material komposit yang diperkuat serat pelepah sagu

Urgensi penelitian ini, untuk mengetahui kekuatan mekanik variasi diameter serat pelepah sagu yang sebelumnya dilakukan perendaman (diberi perlakuan) dengan zat kimia Natrium Hidroksida $(\mathrm{NaOH})$ yang dicampur dengan Aquades (H2O) (Humeiri, 2013). Setalah diketahui diameter serat pelepah sagu yang terbaik, selanjutnya dilakukan pengujian lanjutan (uji mekanik tarik) terhadap material komposit yang diperkuat serat pelepah sagu. Dengan demikian serat alami pelepah sagu dapat digunakan sebagai alternatif pengganti serat sisntesis.

\section{MATERIAL KOMPOSIT}

Material komposit adalah material multi fasa yang diperoleh melalui kombinasi dari dua material atau lebih yang memiliki karakteristik sifat yang berbeda, digabungkan untuk mencapai sifat karakteristik yang lebih baik dan tidak dimiliki material penyusunnya (Chung, 2010). Material komposit didefenisikan sebagai sebuah material yang terdiri atas beberapa material, dimana sifat yang dimilikinya merupakan gabungan sinergis dari sifat material penyusunnya. Berdasarkan morfologi material penguatnya, komposit dibagi dalam tiga kelompok, yaitu Komposit partikulat, Kompist serat; dan Komposit laminat (Sofian, 2010).

Komposit untuk pada dasarnya campuran bahan-bahan yang terdiri dari, Campuran cairan resin (water glass), Katalis dan serat fiber, proses pembuatannya semua bahan tadi dicampur, sehingga akan bereaksi dari bahan berbentuk cair berubah menjadi padat (Chandramohan \& Kumar, 2017). Material pembentuk komposit tersebut dapat diuraikan sebagai berikut:

1. Resin

Resin merupakan bahan pembuat fiberglass yang berwujud cairan kental seperti lem. Berfungsi untuk mengeraskan semua bahan yang akan dicampur menjadi larutan fiberglass. Resin memiliki berbagai macam jenis type, dari yang keruh, berwarna, hingga yang bening dengan berbagai kelebihan seperti kekerasan, lentur, kakuatan dan lain-lain. Resin polyester, fiberglass resin atau resin kapal banyak dipasarkan di dunia khususnya Indonesia dengan warna yang berbeda-beda seperti merah, putih kekuning-kuningan dan hijau yang akan telihat sedikit transparan apabila diaplikasikan dalam lapisan yang relatif tipis. Penggunaan jenis polyester resin diperkirakan sekitar $70 \%$ dalam seluruh penggunaan seluruh jenis resin diseluruh dunia. Resin merupakan bahan pembuat fiberglass yang berwujud cairan kental seperti lem. Berfungsi untuk mengeraskan semua bahan yang akan dicampur menjadi larutan fiberglass. Resin memiliki berbagai macam jenis type, dari yang keruh, berwarna, hingga yang bening dengan berbagai kelebihan seperti kekerasan, lentur, kakuatan dan lain-lain (Chung, 2010)

2. Katalis

Katalis juga adalah suatu zat yang mempercepat laju reaksireaksi kimia pada suhu tertentu, tanpa mengalami perubahan atau terpakai oleh reaksi itu sendiri. Suatu katalis berperan dalam reaksi tapi bukan sebagai pereaksi ataupun produk. Katalisis merupakan proses yang terjadi akibat adanya peran dari katalis. Katalis merupakan senyawa kimia yang dapat mempercepat reaksi tanpa perubahan bentuk/struktur dari katalis tersebut. Cara kerjanya yaitu dengan menempel pada bagian subtrat tertentu dan pada akhirnya dapat menurunkan energi pengaktifan dari reaksi, sehingga reaksi berlangsung dengan cepat. Katalis memungkinkan reaksi berlangsung lebih cepat atau memungkinkan reaksi pada suhu lebih rendah akibat perubahan yang dipicunya terhadap pereaksi. Katalis menyediakan suatu jalur pilihan dengan energi aktivasi yang lebih rendah. Katalis mengurangi energi yang dibutuhkan untuk berlangsungnya reaksi. Katalis berbentuk cair, berwarna bening dan berbau sengat. Bahan ini tergolong jenis bahan kimia yang berbahaya. Jika kulit terkena langsung dengan bahan ini kulit akan terasa panas seperti terbakar dan akan mengalami iritasi. Katalis digunakan untuk mempercepat proses pengerasan adonan fiberglass.(Chung, 2010) 


\section{Serat Sintesis (Fiber)}

Serat Kaca (fiberglass), dipasaran dikenal dengan nama meet atau roving. Sering diterjemahkan menjadi serat gelas adalah kaca cair yang ditarik menjadi serat tipis dengan garis tengah sekitar 0,005 $\mathrm{mm}-0,01 \mathrm{~mm}$. Serat ini dapat dipintal menjadi benang atau ditenun menjadi kain, yang kemudian diresapi dengan resin sehingga menjadi bahan yang kuat dan tahan korosi untuk digunakan sebagai badan mobil dan bangunan kapal. Serat Kaca juga digunakan sebagai agen penguat untuk banyak produk plastik; material komposit yang dihasilkan dikenal sebagai plastik diperkuat gelas (glass-reinforced plastic, GRP) atau epoxy diperkuat glass - fiber (GRE), disebut "fiberglass" dalam penggunaan umumnya (Ramalan, 2015).

\section{Serat Pelepah Sagu}

Tanaman sagu dengan bahasa latin (Metroxylon sp) berarti tanaman yang menyimpan pati pada batangnya. Pohon sagu memiliki batang silindris mirip pohon kelapa, tetapi ukuran diameter batangnya cukup besar sehingga apabila telah dewasa batangnya tidak terpeluk oleh manusia. Secara keseluruhan, pohon sagu lebih terlihat sebagai palem yang gemuk. (Wibisono, 2011). Sagu dari genus Metroxylon, secara garis besar digolongkan menjadi dua, yaitu : yang berbunga atau berbuah dua kali (Pleonanthic) dan berbunga atau berbuah sekali (Hapaxanthic) yang mempunyai nilai ekonomis penting, karena kandungan karbohidratnya lebih banyak. Jumlah curah hujan yang optimal bagi pertumbuhan sagu antara $2.000-4.000 \mathrm{~mm} /$ tahun, yang tersebar merata sepanjang tahun (Gunawan, 2016). Sagu dapat tumbuh sampai pada ketinggian $700 \mathrm{mdpl}$, namun produksi sagu terbaik ditemukan sampai ketinggian $400 \mathrm{mdpl}$ (Lestari, 2010). Sagu paling baik bila ditanam pada tanah yang mempunyai pengaruh pasang surut, terutama bila air pasang tersebut merupakan air segar. Lingkungan yang paling baik untuk pertumbuhannya adalah daerah yang berlumpur, dimana akar nafas tidak terendam. Pertumbuhan sagu juga dipengaruhi oleh adanya unsur hara yang disuplai dari air tawar, terutama potasium, fosfat, kalsium, dan magnesium (Lestari, 2010)

Dari hasil pengolahan tepung sagu meninggalkan beberapa limbah, salah satu limbah tersebut adalah tungkai daun sagu (Pelepah Sagu). Sedangakan apabila diamati secara seksama didalam kulit pelepah sagu terdapat serat yang kuat menyerupai bulu rambut (Supu, Tenriawaru, Cambaba, 2017).

Pengujian Material, digunakan analisis data secara statistik, yaitu analisis data dengan menggambarkan kualitas material secara umum yang disajikan dalam bentuk table maupun grafik sesuai dengan standar ASTM D 638 - 02 dan ASTM D-638 M (M-I).

Waktu dan Lokasi, Penelitian ini diadakan di 3 tempat, pengambilan material di pusat pengolahan sagu Kelurahan Jaya Kecamatan Telluwanua Kota Palopo, perlakuan material dengan bahan kimiawi di laboratorium Fakultas Teknik Universitas Andi Djemma Palopo dan pengambilan data di lakukan di Balai Latihan Kerja (BLK) Makassar. Dalam skala laboratorium membutuhkan waktu selama \pm 6 bulan. (Mei s/d Oktober 2020). Serat pelepah sagu diperoleh dari proses pengerjaan secara manual, dan dilanjutkan dengan proses ekstrasi larutan alkali Natrium Hidrosida $(\mathrm{NaOH})$ dan Aquades $(\mathrm{H} 2 \mathrm{O})$. Bahan komposit resin Polyester dan katalis Ziegler - Natta dengan perbandingan 1 : $100 \mathrm{ml}$. Pembuatan komposit dilakukan dengan metode hand lay up. Pengujian komposit menggunakan mesin Universal Testing merek Simadzu.

Pengubah yang diamati

1. Pemisahan serat dengan lignin, Proses perendaman dengan menggunakan persentase campuran $\mathrm{NaOH}$ dan $\mathrm{H} 2 \mathrm{O}$ yang bervariasi $(0 \%, 2,5 \%, 5 \%, 7,5 \%, 10 \%)$, selama 15 menit untuk menghilangkan lignin/kotoran yang melekat pada serat.

2. Uji Material Serat Skala Laboratorium, Menggunakan standar ASTM D 638 - 02 untuk pengujian mekanik serat dan ASTM D-638 M (M-I) untuk pengujian mekanik komposit yang diperkuat serat pelepa sagu.

\section{HASIL DAN PEMBAHASAN}

Hasil Penelitian, Untuk mengetahui hubungan ukuran serat terhadap pengaruh NAoH, kekuatan Tarik serat dan kekuatan Tarik serta bending komposit serat sagu, maka dalam penelitian ini akan diinteprestasikan secara grafikal untuk melihat kecenderungan atau keterkaitan antara variable.

Rendaman specimen dilarutan $\mathbf{N a O H}$, Perendaman serat pelepah sagu kedalam larutan $\mathrm{NaOH}$ dengan persentase $(0 \%, 2,5 \%, 5 \%, 7,5 \%$ dan $10 \%)$ selama 15 menit didalam sebuah wadah, bertujuan untuk melepas lignin yang melekat pada serat pelepah sagu.

Material serat sagu yang digolongkan kedalam 3 ukuran spesimen material, sebagai berikut; (a) 
Kelompok 1. Ukuran Serat $\varnothing 0,05$ - 0,25. (b). Kelompok 2 Ukuran Serat $\varnothing 0,30$ - 0,50. (c). Kelompok 3. Ukuran Serat $\varnothing 0,55-0,75$. Dari hasil pengukuran menggunakan mikrometer berikut hasil yang didapatkan dalam penelitian ini.

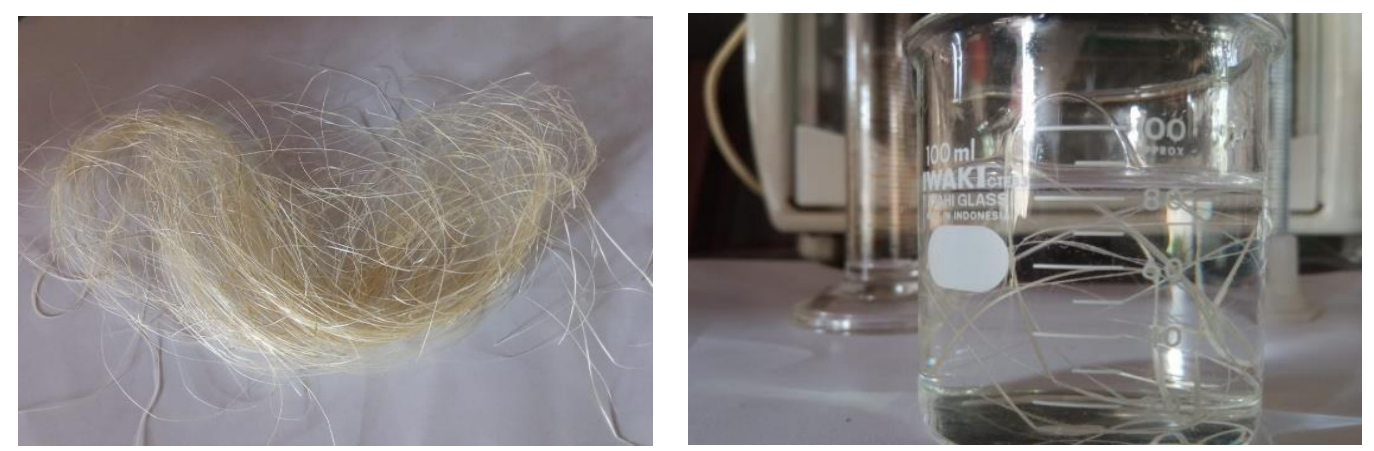

Gambar 1. Serat sagu dan perendaman sedalam larutan $\mathrm{NaOH}+\mathrm{H}_{2} \mathrm{O}$

Tabel 1. Data diameter serat sagu Kelompok 1

\begin{tabular}{|c|c|c|c|c|c|c|c|}
\hline No. & Konsentrasi & \multicolumn{7}{|c|}{ Kelompok 1 (Ukuran Serat 0,05 - 0,25) } \\
\cline { 3 - 8 } & NaOH + H20 & KDS & $\emptyset$ & KDS & $\emptyset$ & KDS & $\emptyset$ \\
\hline 1 & $0 \%$ & KR101 & 0,11 & KR102 & 0,15 & KR103 & 0,25 \\
\hline 2 & $2,5 \%$ & KR111 & 0,10 & KR112 & 0,16 & KR113 & 0,23 \\
\hline 3 & $5 \%$ & KR121 & 0,12 & KR122 & 0,15 & KR123 & 0,23 \\
\hline 4 & $7,5 \%$ & KR131 & 0,10 & KR132 & 0,17 & KR133 & 0,21 \\
\hline 5 & $10 \%$ & KR141 & 0,13 & KR142 & 0,15 & KR143 & 0,25 \\
\hline
\end{tabular}

Tabel 2. Data diameter serat sagu Kelompok 2

\begin{tabular}{|c|c|c|c|c|c|c|c|}
\hline No. & Konsentrasi & \multicolumn{7}{|c|}{ Kelompok 2 (Ukuran Serat 0,30 - 0,50) } \\
\cline { 3 - 8 } & NaOH + H20 & KDS & $\emptyset$ & KDS & $\emptyset$ & KDS & $\emptyset$ \\
\hline 1 & $0 \%$ & KR201 & 0,31 & KR202 & 0,42 & KR203 & 0,48 \\
\hline 2 & $2,5 \%$ & KR211 & 0,33 & KR212 & 0,40 & KR213 & 0,47 \\
\hline 3 & $5 \%$ & KR221 & 0,35 & KR222 & 0,42 & KR223 & 0,50 \\
\hline 4 & $7,5 \%$ & KR231 & 0,37 & KR232 & 0,41 & KR233 & 0,46 \\
\hline 5 & $10 \%$ & KR241 & 0,35 & KR242 & 0,40 & KR243 & 0,69 \\
\hline
\end{tabular}

Tabel 3. Data diameter serat sagu Kelompok 3

\begin{tabular}{|c|c|c|c|c|c|c|c|}
\hline \multirow{2}{*}{ No. } & Konsentrasi & \multicolumn{6}{|c|}{ Kelompok 3 (Ukuran Serat 0,55 - 0,75) } \\
\cline { 3 - 8 } & NaOH + H20 & KDS & $\boldsymbol{\emptyset}$ & KDS & $\emptyset$ & KDS & $\emptyset$ \\
\hline 1 & $0 \%$ & KR301 & 0,65 & KR302 & 0,70 & KR303 & 0,55 \\
\hline 2 & $2,5 \%$ & KR311 & 0,64 & KR312 & 0,67 & KR313 & 0,57 \\
\hline 3 & $5 \%$ & KR321 & 0,63 & KR322 & 0,72 & KR323 & 0,70 \\
\hline 4 & $7,5 \%$ & KR331 & 0,65 & KR332 & 0,73 & KR333 & 0,59 \\
\hline 5 & $10 \%$ & KR341 & 0,67 & KR342 & 0,65 & KR343 & 0,56 \\
\hline
\end{tabular}

Kekuatan Tarik Serat Sagu, Sebagai parameter dalam pengujian specimen dalam penelitian ini, serat kaca dijadikan sebagai tolak ukur kuat Tarik $\left(323 \mathrm{~N} / \mathrm{mm}^{2}\right)$. Berikut ini hasil pengujian specimen di laboratorium material Balai Latihan Kerja (BLK) Kota Makssar Provinsi Sulawesi Selatan. Tanggal, 2 September 2020.

Tabel 4. Data Hasil pengujian Tarik serat sagu Kelompok 1

NaOH $\quad$ Kelompok 1 (Ukuran Serat 0,05 - 0,25)




\begin{tabular}{|c|c|c|c|c|c|c|c|c|}
\hline No. & $+\mathrm{H}_{2} \mathrm{O}$ & KDS & $\left(\mathrm{N} / \mathrm{mm}^{2}\right)$ & KDS & $\left(\mathrm{N} / \mathrm{mm}^{2}\right)$ & KDS & $\left(\mathrm{N} / \mathrm{mm}^{2}\right)$ & $\begin{array}{c}\text { Rata - } \\
\text { rata }\end{array}$ \\
\hline 1 & $0 \%$ & KR101 & 46.560 & KR102 & 48.631 & KR103 & 45.540 & 46.910 \\
\hline 2 & $2,5 \%$ & KR111 & 47.230 & KR112 & 49.486 & KR113 & 48.590 & 48.435 \\
\hline 3 & $5 \%$ & KR121 & 45.920 & KR122 & 47.231 & KR123 & 43.560 & 45.570 \\
\hline 4 & $7,5 \%$ & KR131 & 42.587 & KR132 & 44.230 & KR133 & 40.890 & 42.569 \\
\hline 5 & $10 \%$ & KR141 & 31.513 & KR142 & 34.245 & KR143 & 29.782 & 31.847 \\
\hline
\end{tabular}

Tabel 5. Data Hasil pengujian Tarik serat sagu Kelompok 2

\begin{tabular}{|c|c|c|c|c|c|c|c|c|}
\hline \multirow[b]{2}{*}{ No. } & \multirow{2}{*}{$\begin{array}{l}\mathrm{NaOH} \\
+\mathrm{H}_{2} \mathrm{O}\end{array}$} & \multicolumn{7}{|c|}{ Kelompok 2 (Ukuran Serat 0,30 - 0,50) } \\
\hline & & KDS & $\left(\mathrm{N} / \mathbf{m m}^{2}\right)$ & KDS & $\left(\mathbf{N} / \mathbf{m m}^{2}\right)$ & KDS & $\left(\mathrm{N} / \mathbf{m m}^{2}\right)$ & $\begin{array}{c}\text { Rata - } \\
\text { rata }\end{array}$ \\
\hline 1 & $0 \%$ & KR201 & 45.002 & KR202 & 43.672 & KR203 & 43.056 & 43.910 \\
\hline 2 & $2,5 \%$ & KR211 & 47.560 & KR212 & 46.985 & KR213 & 46.860 & 47.135 \\
\hline 3 & $5 \%$ & KR221 & 44.901 & KR222 & 42.101 & KR223 & 45.098 & 44.033 \\
\hline 4 & $7,5 \%$ & KR231 & 38.760 & KR232 & 39.012 & KR233 & 32.090 & 36.621 \\
\hline 5 & $10 \%$ & KR241 & 30.883 & KR242 & 32.093 & KR243 & 25.045 & 29.340 \\
\hline
\end{tabular}

Tabel 6. Data Hasil pengujian Tarik serat sagu Kelompok 3

\begin{tabular}{|c|c|c|c|c|c|c|c|c|}
\hline \multirow[b]{2}{*}{ No. } & \multirow{2}{*}{$\begin{array}{l}\mathrm{NaOH} \\
+\mathrm{H}_{2} \mathrm{O}\end{array}$} & \multicolumn{7}{|c|}{ Kelompok 3 (Ukuran Serat 0,55 - 0,75) } \\
\hline & & KDS & $\left(\mathrm{N} / \mathrm{mm}^{2}\right)$ & KDS & $\left(\mathrm{N} / \mathbf{m m}^{2}\right)$ & KDS & $\left(\mathrm{N} / \mathrm{mm}^{2}\right)$ & $\begin{array}{c}\text { Rata - } \\
\text { rata }\end{array}$ \\
\hline 1 & $0 \%$ & KR301 & 43.672 & KR302 & 43.550 & KR303 & 43.572 & 43.598 \\
\hline 2 & $2,5 \%$ & KR311 & 44.950 & KR312 & 45.257 & KR313 & 44.865 & 45.024 \\
\hline 3 & $5 \%$ & KR321 & 43.560 & KR322 & 38.760 & KR323 & 39.015 & 40.445 \\
\hline 4 & $7,5 \%$ & KR331 & 39.012 & KR332 & 32.096 & KR333 & 32.390 & 34.499 \\
\hline 5 & $10 \%$ & KR341 & 25.043 & KR342 & 27.980 & KR343 & 26.67 & 26.564 \\
\hline
\end{tabular}

Dari table diatas dapat dibuatkan grafik hubungan antara perlakuan perenadaman laruatan $\left(\mathrm{NaOH}+\mathrm{H}_{2} \mathrm{O}\right)$ dan variasi ukuran serat terhadap kekuatan tarik. Berikut grafik rata - rata Kekuatan Tarik.

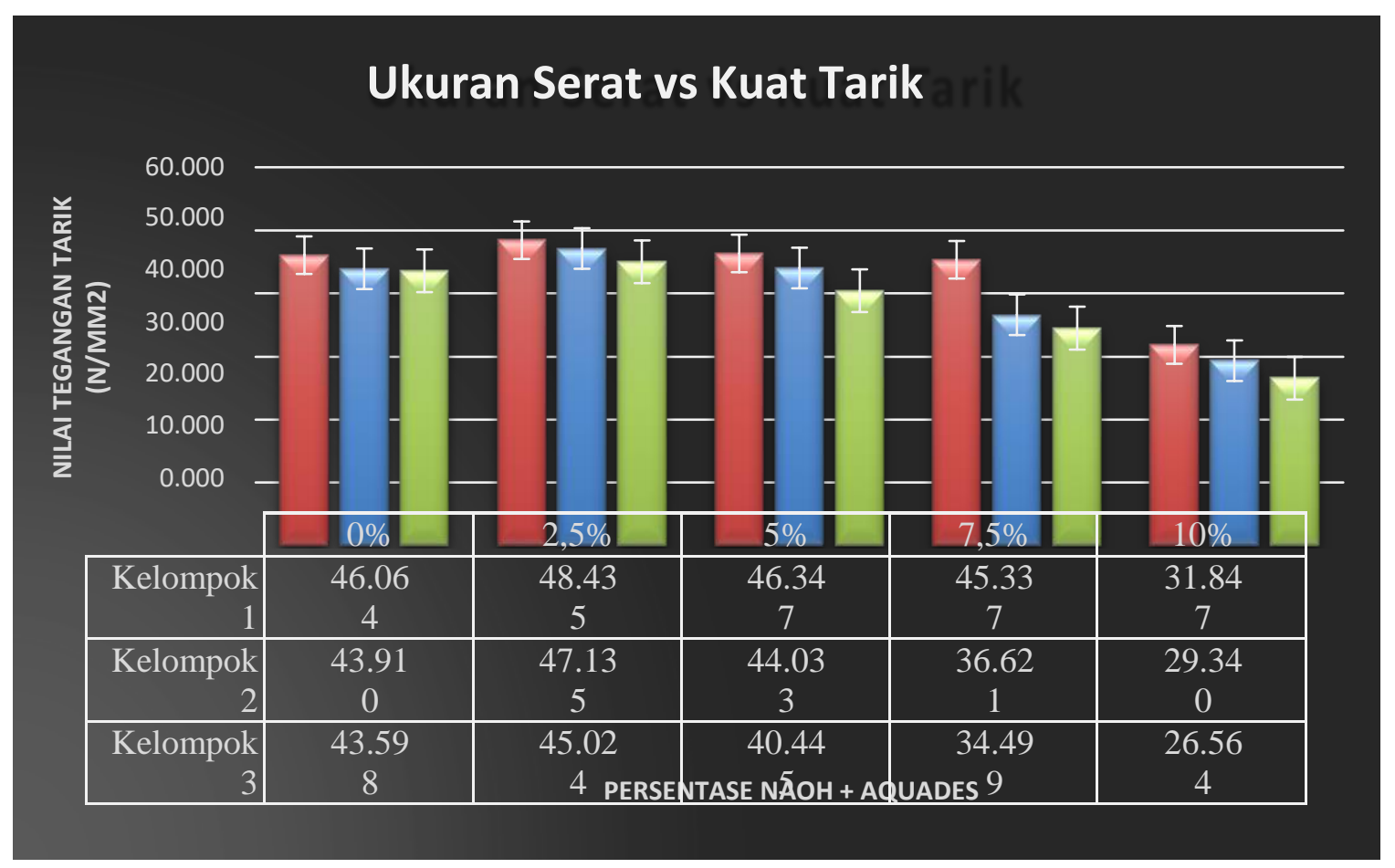


Gambar 2. Rata - rata nilai tegangan Tarik pada serat sagu

Gambar 5 diatas menunjukkan nilai rata - rata hubungan antara perlakuan perenadaman laruatan $(\mathrm{NaOH}$ $+\mathrm{H}_{2} \mathrm{O}$ ) dan variasi ukuran serat terhadap kekuatan tarik. Dari grafik tersebut menggambarkan bahwa kekuatan tarik yang terdapat pada specimen, sebagai berikut;

a. Larutan $\mathrm{NaOH}$ berpengaruh terhadap kuat Tarik specimen, hal ini ditunjukkan pada 2,5\% (NAoH terhadap $\mathrm{H}_{2} \mathrm{O}$ ). Nilai kekuatan tariknya lebih tinggi dari perlakuan yang diberikan kepada specimen KR112 $\varnothing 0,10 \mathrm{~mm}$ dengan kuat Tarik 49,486 N/mm ${ }^{2}$ dan nilai kuat Tarik terendah terdapat pada KR341 $\varnothing 0,67 \mathrm{~mm}$ dengan kutat Tarik 25,043 N/mm². Dengan komposisi laruatan $10 \%$ ( $\mathrm{NAoH}$ terhadap $\mathrm{H}_{2} \mathrm{O}$ ).

b. Variasi ukuran besar diameter serat pelepah sagu dari hasil pengujian berbanding terbalik. Bahwa semakin besar ukuran serat yang diberikan maka semakin kecil kekuatan tarik yang didapatkan. Hal ini dapat dilihat pada komposisi larutan 2,5\%, dengan ukuran serat kelompok 1 ( $\varnothing 0.05-0.25 \mathrm{~mm}$ ) memiliki kekuatan Tarik rata - rata sebesar 48,435 N/mm², ukuran serat Kelompok 2 (Ø $0.30-0.50$ $\mathrm{mm}$ ) memiliki kekuatan tarik rata - rata sebesar $47.135 \mathrm{~N} / \mathrm{mm}^{2}$, dan untuk kelompok 3 (Ø $0.55-0,75$ $\mathrm{mm}$ ) memiliki kekuatan tarik rata - rata sebesar 45,024 N/mm².

Uraian diatas diperoleh nilai kekuatan tarik rata - rata yang terbesar terdapat pada spesimen ukuran serat kelompok 1 (Ø $0.05-0.25 \mathrm{~mm}$ ) dengan komposisi 2,5\% ( $\mathrm{NAoH}$ terhadap $\mathrm{H}_{2} \mathrm{O}$ ), yang merupakan ukuran diameter paling kecil. Hal ini disebabkan tingkat kerapatan susunan antar serat pada ukuran diameter kecil lebih tinggi dibandingkan dengan ukuran diameter yang besar. Sehingga rongga antar serat yang terjadi pada susunan diameter kecil lebih rendah dibandingkan dengan diameter besar dan mengurangi kemampuan serat pelepah sagu dalam menerima beban, sebab ikatan antar unsur penyusun serat melemah.

Kekuatan Tarik Komposite Serat Sagu, Berdasarkan ASTM D-638 M (M-I) geometri spesimen uji Tarik, dengan gambar sebagai berikut;

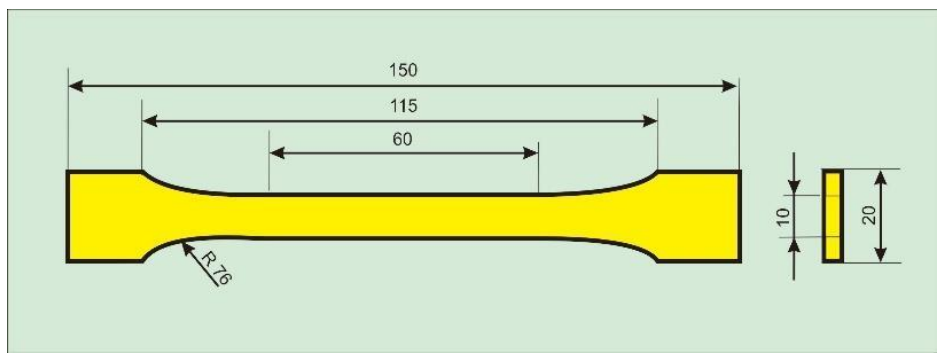

Gambar 3. Geometri Spesimen Uji Tarik

Pada pembuatan specimen untuk komposit digunakan serat sagu dengan $\varnothing 0,05-0,25 \mathrm{~mm}$ dengan perendaman $\mathrm{NaOH} 25 \%$ selama 15 menit. Pembuatan cetakan untuk membentuk specimen komposit dengan metode hand lay up. Spesimen uji yang dipersiapkan berjumlah 9 (sembilan) buah yang dibagi menjadi 3 (tiga) Komposisi volume serat pelepah sagu. Dengan setiap komposisi volume serat pelepah sagu berjumlah 3 (tiga) buah specimen uji.

Pembuatan material Uji dengan Komposisi volume serat yang pertama yaitu (A). Komposisi 95\% matriks (Resin + Katalis) : $5 \%$ serat pelepah sagu,

(B) Komposisi volume $90 \%$ matriks (Resin + Katalis) : 10\% serat pelepah sagu. (C) Komposisi volume 85\% matriks (Resin + Katalis) : 15\% serat pelepah sagu. Untuk lebih jelas dapat dilihat pada gambar berikut ini. 


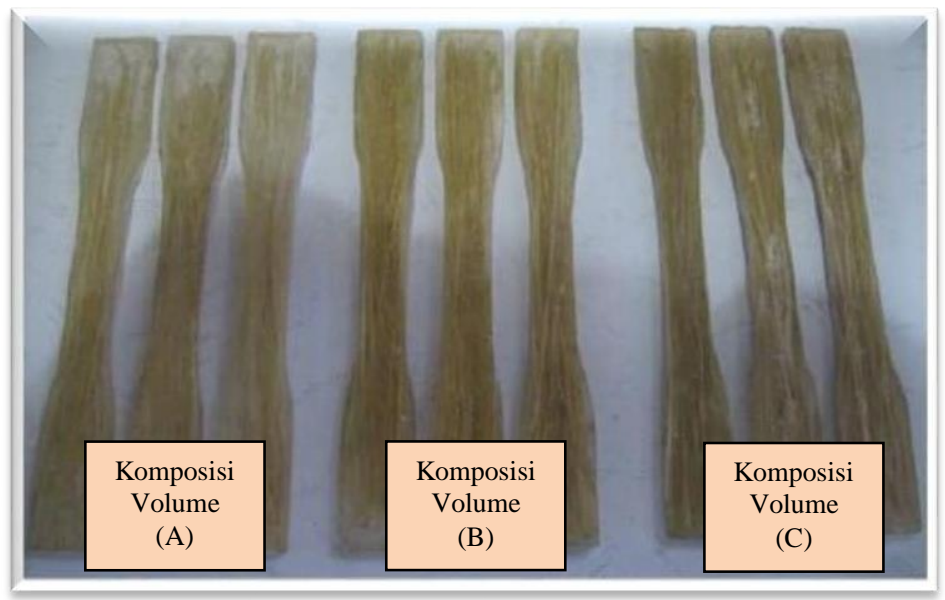

Gambar 4. Spesimen Uji

Kuat Tarik merupakan tegangan maksimum yang mampu ditahan oleh suatu material sebelum patah (Badaron, et al, 2019). Pengujian tarik dilakukan di BLK Makassar Provinsi Sulawesi Selatan. Tanggal, 23 September 2020, untuk mengetahui kemampuan dari komposit pada setiap fraksi volume serat. Patahan komposit yang terjadi yaitu jenis patahan LGM (Lateral at Grip Middle) atau patahan pada bagian tengah specimen dengan komposisi yang berbeda. Kondisi tersebut akan menunjukkan patahan terjadi sudah baik yang berarti load terdistribusi secara merata. Data kekuatan tarik yang diperoleh dalam pengujian dapat dilihat pada tabel 9, berikut;

Tabel 7. Komposisi A

\begin{tabular}{|c|c|c|}
\hline \multirow{2}{*}{ No. } & \multicolumn{2}{|c|}{ Kelompok Volume Matriks dan Serat (Mpa) } \\
\cline { 2 - 3 } & Serat 5\% $(\mathbf{A})$ & Beban $(\mathbf{N})$ \\
\hline $\mathbf{1}$ & 2.52 & 9238.00 \\
\hline $\mathbf{2}$ & 2.71 & 9751.00 \\
\hline $\mathbf{3}$ & 2.12 & 8378.00 \\
\hline Rata - rata & $\mathbf{2 . 4 5}$ & $\mathbf{9 1 2 2 . 3 3}$ \\
\hline
\end{tabular}

Dari table diatas kita dapat membuat suatu grafik untuk mempermudah dalam membandingkan kekuatan tarik antara setiap item dalam komposisi A. Pada spesimen uji A1 Kuat Tarik 2,52 MPa beban 9238 N, A2 Kuat Tarik 2.71 MPa beban $9751 \mathrm{~N}$ dan Specimen Uji A3 kuat Tarik 2,12 Beban 8378 N.

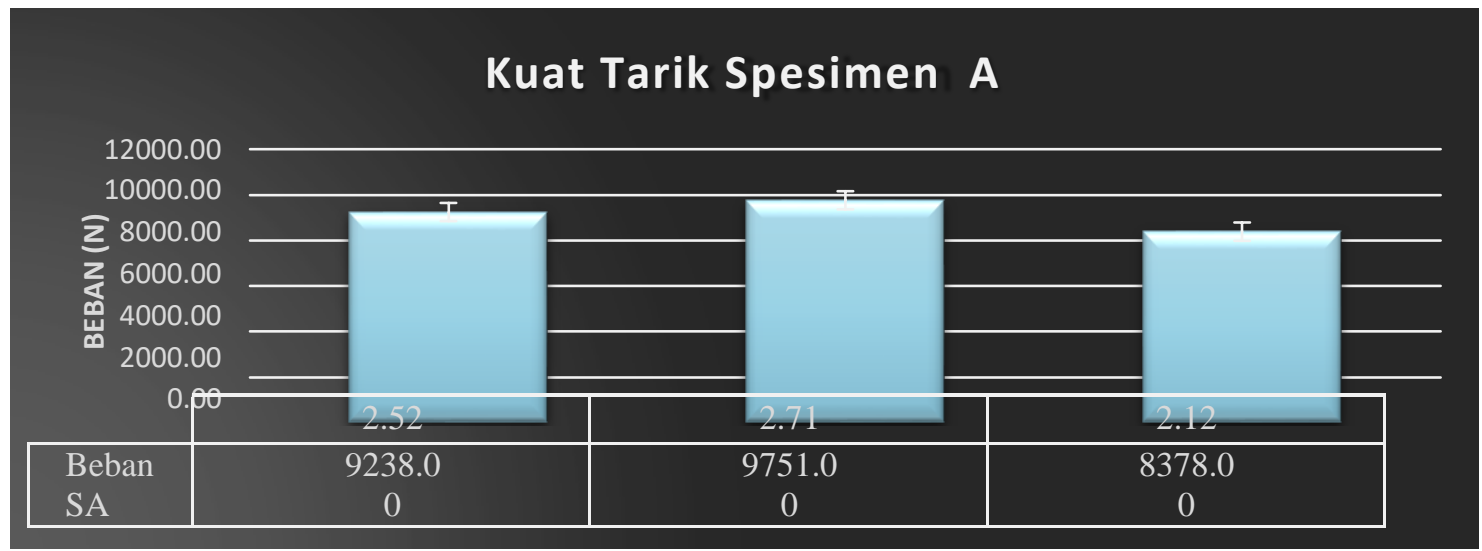

Gambar 5. Grafik Hubungan Kekuatan Tarik dengan Spesimen A1, A2 dan A3

Dari grafik diatas dapat dilihat, terjadi kenaikan pada kekuatan tarik pada spesimen dan terjadi kenaikan beban yang dapat ditahan oleh specimen hingga putus dari specimen A1 (2,52 MPa) ke A2 (2,71 MPa) dan pada specimen A3 terjadi penurunan yang signifikan dengan kuat Tarik komposit 2,12 MPa dengan Beban yang diterima 8378 N. Rata - rata kuat Tarik untuk specimen dengan komposisi matriks (Resin + Katalis) 95\% : $5 \%$ Serat Pelepah Sagu 2.45 MPa dan beban 9122.33 N. 
Untuk mempermudah dalam membandingkan kekuatan tarik antara setiap item dalam komposisi B. Pada spesimen uji B1 Kuat Tarik 2,81 MPa beban 9858 N, B2 Kuat Tarik 2.80 MPa beban 9456 N dan Specimen Uji B3 Kuat Tarik 2,85 Beban 10828 N.

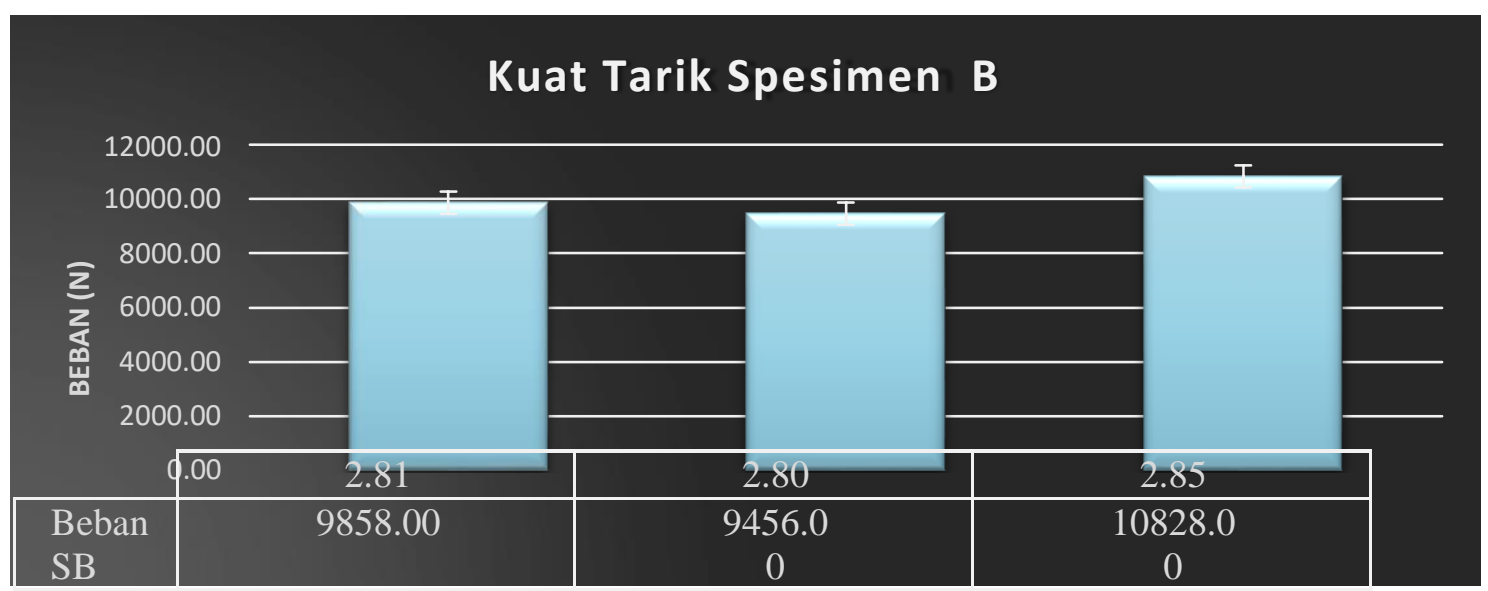

Gambar 6. Grafik Hubungan Kekuatan Tarik dengan Spesimen B1, B2 dan B3

Dari grafik diatas terjadi Penurunan kuat tarik dari specimen B1 ke B2 dan penurunan beban yang dapat ditahan oleh specimen hingga putus, namun pada specimen dari B2 ke B3 kuat Tarik naik secara signifikan dari 2,80 MPa menjadi 2,85 MPa pada beban yang ditahan $9456 \mathrm{~N}$ ke $10828 \mathrm{~N}$. Rata - rata kuat Tarik untuk specimen dengan komposisi matriks (Resin + Katalis) 90\%: $10 \%$ Serat Pelepah Sagu 2.82 MPa dan beban $10047.33 \mathrm{~N}$.

Untuk mempermudah dalam membandingkan kekuatan tarik antara setiap item dalam komposisi C. Pada spesimen uji C1 Kuat Tarik 2,91 MPa beban 10305 N, C2 Kuat Tarik 3,12 MPa beban 11824 N dan Specimen Uji C3 kuat Tarik 2,95 Beban 10948 N.

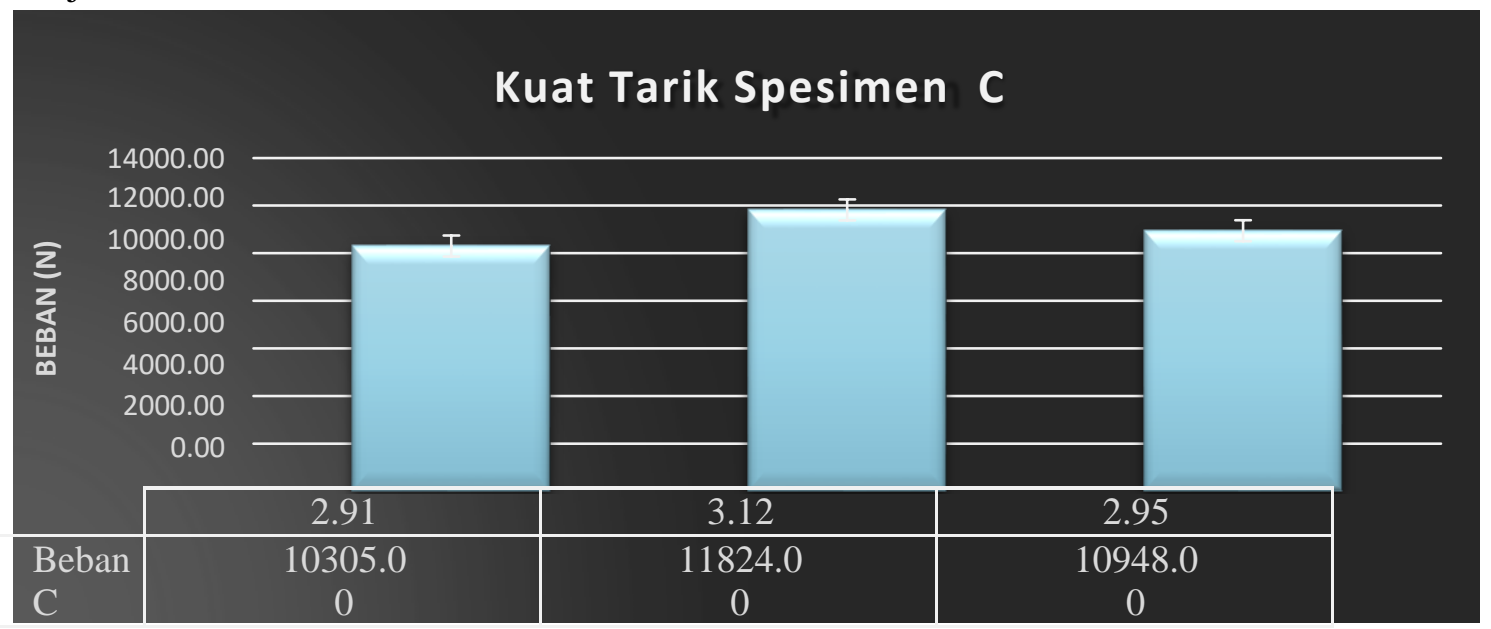

Gambar 7. Grafik Hubungan Kekuatan Tarik pada Spesimen C1, C2 dan C3

Dari grafik diatas dapat dilihat, terjadi Kenaikan kuat tarik pada spesimen dan penurunan beban yang dapat ditahan oleh specimen hingga putus dari specimen C1 (2,9 MPa) ke specimen C2 (3,21 MPa) dan turun secara signifikan ke specimen C3 (2,95 MPa). Rata - rata kuat Tarik untuk specimen dengan komposisi matriks (Resin + Katalis) 85\%: 15\%, Serat Pelepah Sagu 2,99 MPa.

Pembahasan Berdasarkan hasil uraian diatas diperoleh kekuatan tarik serat pelepah sagu dipengaruhi oleh beberapa faktor, seperti kekuatan diameter serat pelepah sagu, panjang serat pelepah sagu, karateristik penyusunnya dan konsentrasi $\mathrm{NAoH}+\mathrm{H}_{2} \mathrm{O}$. Didalam serat pelepah sagu, terdapat unsur kayu dan unsur pati (zat tepung). Unsur pati tersebut memiliki sifat yang lunak, dan rapuh sehingga lignin yang berada disekitar serat pelepah sagu akan berpengaruh terhadap kuat Tarik. Selain itu diameter yang besar memiliki zat pati yang tinggi, dibandingkan dengan serat berdiameter kecil. Hal dapat dilihat dari penelitian yang telah dilakukan. Larutan $\mathrm{NaOH}$ berpengaruh terhadap kuat Tarik specimen, ditunjukkan pada specimen KR112 dengan kuat Tarik 49,486 N/mm2 dan nilai kuat Tarik terendah terdapat pada specimen KR341 Ø 0,67 mm 
dengan kutat Tarik 25,043 N/mm2. Dari hasil analisis data diketahui bahwa serat pelepah sagu kuat tariknya jauh dibawah serat gelas. $(48,435 \mathrm{~N} / \mathrm{mm} 2<323 \mathrm{~N} / \mathrm{mm} 2)$. Hal ini disebabkan rongga yang terdapat di serat sintesis lebih rapat dibanding serat alami.

Komposit Serat Pelepah Sagu, Dari hasil analisis diatas nilai kekuatan tarik tertinggi terdapat pada spesimen uji C2 3,12 beban $11824 \mathrm{~N}$ dan nilai kekuatan Tarik terendah terdapat pada spesimen uji A3 212 beban $8378 \mathrm{~N}$ dan hanya satu spesimen uji yang dibuatkan kurva tegangan regangan. Hal ini disebabkan hanya satu spesimen terjadi regangan dan putus tepat pada titik load. Sedangkan di titik yang lain tidak, dibuat kurva disebabkan tidak adanya regangan dan bentuk kurva sehingga tidak memungkinkan untuk ditampilkan karena bentuknya datar. Spesimen yang mengalami regangan dan patah pada titik load yaitu pada komposisi volume $85 \%$ matriks : $15 \%$ serat (specimen uji C 2). Kekuatan tarik maksimum terjadi pada titik 3,12 MPa dengan regangan sebesar 8\%. Modulus young yang terjadi sebesar 38,615 MPa.

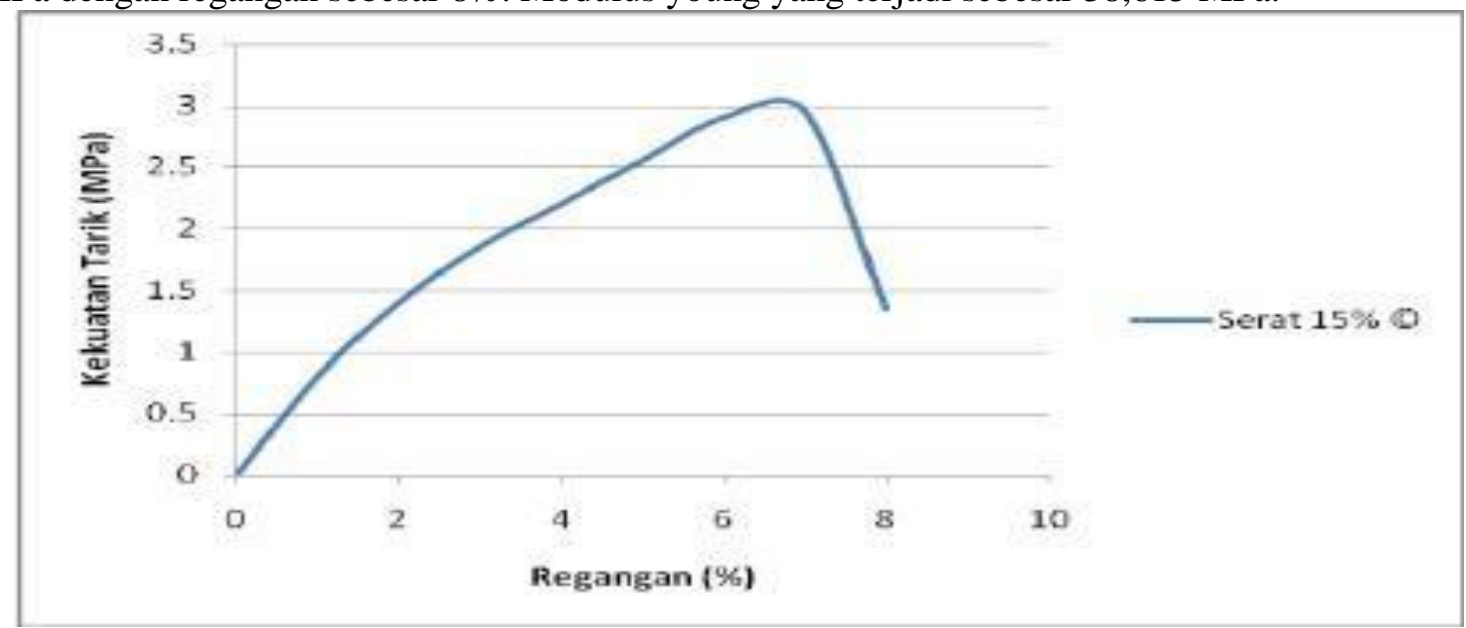

Gambar 8. Kurva Tegangan Regangan specimen uji C 2

\section{PENUTUP}

Kesimpulan, Berdasarkan hasil penelitian dapat disimpulkan sebagai berikut; (1) Larutan $\mathrm{NaOH}$ berpengaruh terhadap kuat Tarik specimen, hal ini ditunjukkan pada 2,5\% (NAoH terhadap Aquades). Nilai kekuatan tariknya lebih tinggi dari perlakuan yang diberikan kepada specimen $\varnothing 0,10 \mathrm{~mm}$ dengan kuat Tarik $49,486 \mathrm{~N} / \mathrm{mm}^{2}$ dan nilai kuat Tarik terendah terdapat pada $\varnothing 0,67 \mathrm{~mm}$ dengan kutat Tarik $25,043 \mathrm{~N} / \mathrm{mm}^{2}$. Dengan komposisi laruatan 10\% (NAoH terhadap Aquades). (2) Serat pelepah sagu kuat tariknya jauh dibawah serat gelas. $\left(48,435 \mathrm{~N} / \mathrm{mm}^{2}<323 \mathrm{~N} / \mathrm{mm}^{2}\right)$. Hal ini disebabkan rongga yang terdapat di serat sintesis lebih rapat dibanding serat alami. (3) Berdasarkan variabel yang diteliti, kekuatan tarik $\left(F^{t u}\right)$ dengan nilai tertinggi terjadi pada komposit C2 (volume 85\% matriks : 15\% serat) yaitu sebesar 3,12 beban $11824 \mathrm{~N}$ sedangkan kekuatan tarik $\left(F^{t u}\right)$ dengan nilai terendah terjadi pada komposit A3 (volume $95 \%$ matriks : 5\% serat) sebesar 2,12 beban 8378 N. (4) Kekuatan tarik mengalami kenaikan terhadap peningkatan komposisi volume serat. (5) Spesimen uji yang mengalami regangan dan patah pada titik load yaitu pada komposisi volume $85 \%$ matriks : $15 \%$ serat sebesar 3,12 MPa dengan regangan sebesar $8 \%$ dan modulus young yang terjadi sebesar 38,615 MPa.

Saran, Dari hasil pengujian yang telah dilakukan, peneliti ingin meyampaikan beberapa saran yaitu; (1) Perlu dilakukan perlakuan atau penelitian lebih lanjut terhadap material serat pelepah sagu agar mendekati kekuatan Tarik yang dimilki oleh serat gelas untuk menambah kualitas. (2) Sebaiknya penempatan serat dilakukan secara baik agar tidak ada daerah yang kekurangan akan serat, terutama pada bagian pencekam (holder). (3) Sebaiknya dilakukan pengujian kembali dengan cara penempatan serat yang berbeda, seperti menyilang atau anyaman untuk mengetahui kekuatan dan hasil yang optimal. (4) Pencampuran matriks dan serat dari komposit harus rata dan hindarilah terjadinya gelembung udara pada saat pembuatan spesimen.

\section{DAFTAR PUSTAKA}

Ahyuni, D. 2011. Pengelolalan Sagu (Metroxylon spp) di PT National Sago Prima, selat panjang, Kab.

Kepulauan Meranti, Riau, dengan Aspek Khusus Pertumbuhan Bibit di Lapangan. Skripsi. Program

Sarjana. Institut Pertanian Bogor. Bogor.

Awual, M. R., Hasan, M. M., Iqbal, J., Islam, M. A., Islam, A., Khandaker, S., ... \& Rahman, M. M. (2020). 
Ligand based sustainable composite material for sensitive nickel (II) capturing in aqueous media. Journal of Environmental Chemical Engineering, 8(1), 103591.

Awual, M. R. (2019). Innovative composite material for efficient and highly selective $\mathrm{Pb}$ (II) ion capturing from wastewater. Journal of Molecular Liquids, 284, 502-510

Badaron, S. F., Gecong, A., Anies, M. K., Achmad, W. M., \& Setiani, E. P. (2019). Studi Perbandingan Kuat Tarik Tidak Langsung terhadap Campuran Aspal Beton dengan menggunakan Limbah Marmer dan Abu Sekam Padi sebagai Filler. PENA TEKNIK: Jurnal Ilmiah Ilmu-Ilmu Teknik, 4(2), 145-155.

Chandramohan, D., \& Kumar, A. J. P. (2017). Experimental data on the properties of natural fiber particle reinforced polymer composite material. Data in brief, 13, 460-468.

Chung Deborah D. L. 2010. Composite Materials Science and Applications. Second Edition. SpringerVerlag: London

Gunawan, Y., \& Aksar, P. (2016). Analisa Pengaruh Ukuran Diameter Serat Tangkai Sagu terhadap Sifat Mekanik pada Material Komposit. Enthalpy, 1(2).

Humeiri, Arif. 2013. Pengaruh konsentrasi alkali dan diameter serat terhadap kuat geser rekatan pada antar muka serat ijuk aren (arenga pinnata)/ poliester. Yogyakarta

Lestari, M.S., S.R. Sihombing, Y.H. Rusmawir, dan R. Kelyanin. 2010. Implementasi Teknologi Pengolahan Sagu Rakyat di Kabupaten Jayapura. http://papua.litbang.deptan.go.id. [9 Agustus 2019]

Ramalan. Laode, 2015. Analisis Kekuatan Tarik Dan Bending Komposit Diperkuat Serat Ijuk. (Skripsi). Universitas Halu Oleo : Kendari

Sofian Bondan. T. 2010. Pengantar material teknik. Salemba Teknika. Jakarta.

Supu, I., Tenriawaru, E. P., \& Cambaba, S. (2017). Sifat Mekanik Kulit Batang Sagu Pada Berbagai Kondisi. The Indonesian Green Technology Journal, 6(1).

Wibisono, M. A. 2011. Pengelolaan Sagu (Metroxylon spp) di PT. National Sagu Prima, Kabupaten Kepulauan Meranti, Riau dengan Studi Kasus Pengaruh Teknik Persemaian dan Jenis Tanaman Induk Terhadap Pertumbuhan Bibit Sagu. (Skripsi) Program Sarjana.. Institut Pertanian Bogor. Bogor.

Yudha Yoga Pratama dkk. 2014, Pengaruh perlakuan alkali, fraksi volume serat, dan panjang serat terhadap kekuatan tarik komposit serat sabut kelapa - polyester. Jurnal Ilmiah Teknik Industri. Universitas Muhammadiyah Surakarta. Surakarta 